\title{
Transformational Creativity: The Link between Creativity, Wisdom, and the Solution of Global Problems
}

\author{
Robert J. Sternberg
}

Citation: Sternberg, R.J.

Transformational Creativity: The Link between Creativity, Wisdom, and the Solution of Global Problems.

Philosophies 2021, 6, 75. https://

doi.org/10.3390/philosophies6030075

Academic Editor: Nicholas Maxwell

Received: 7 August 2021

Accepted: 4 September 2021

Published: 8 September 2021

Publisher's Note: MDPI stays neutral with regard to jurisdictional claims in published maps and institutional affiliations.

Copyright: (C) 2021 by the author. Licensee MDPI, Basel, Switzerland. This article is an open access article distributed under the terms and conditions of the Creative Commons Attribution (CC BY) license (https:// creativecommons.org/licenses/by/ $4.0 /)$.
College of Human Ecology, Cornell University, Ithaca, NY 14853, USA; rjs487@cornell.edu

\begin{abstract}
This article introduces the concept of transformational creativity, which is creativity that is deployed to make a positive, meaningful, and potentially enduring difference to the world. Transformational creativity is compared to transactional creativity, which is creativity deployed in search of a reward, whether externally or internally generated. The article also discusses different kinds of transactional and transformational creativity. For example, some transactional creativity is inert, meaning that it never comes to fruition. Transformational creativity can be directed inward, outward, or both ways. The article also discusses pseudo-transformational creativity, which is offered by the creator as making the world a better place, when in fact its goal is to improve the lot of the person who is pseudo-transformationally creative. Many charismatic leaders are pseudotransformational autocrats. It is concluded that, at this point in time, the world desperately needs the work of transformationally creative individuals.
\end{abstract}

Keywords: creativity; transactional creativity; transformational creativity; pseudo-transformational creativity

If one wishes to understand a construct, one way to do it is to consult experts in the field in which the construct is embedded. In seeking to understand intelligence, creativity, and wisdom, one scholar did just that [1]. Sternberg asked professors in the fields of art, business, philosophy, and physics to rate behaviors that had been provided as relevant in their respective professions for the characteristicness of the behaviors with reference to an extremely intelligent, creative, or wise person.

The results for professors of philosophy were typical: The correlations were 0.56 for intelligence with creativity, 0.42 for intelligence with wisdom, and 0.37 for creativity and wisdom. For experts in all four fields as well as for laypersons, of the three correlations, the correlation of ratings for wisdom and creativity was the lowest. Put another way, intelligence and creativity, on the one hand, and intelligence and wisdom, on the other, were both viewed as psychologically more similar than are creativity and wisdom.

These ratings perhaps make sense in terms of typical Westernized definitions of intelligence, creativity, and wisdom. Intelligence typically is defined in terms of ability to adapt, reason, and learn [2]. Creativity is usually defined in terms of the ability to produce novel and useful ideas [3]. Wisdom is defined in terms of the ability to find a common good, to balance interests, to balance intellectual and emotional responses, and to recognize one's intellectual and other limitations [4]. On these definitions, creativity is about coming up with something new; wisdom is about gaining a balanced perspective on something old (already existing); and intelligence is somewhere in-between.

Experts, like everyone else, are culturally embedded. Put another way, they are experts within a cultural context. In the case of a physicist, their cultural embeddedness may matter somewhat less. An atom is an atom, wherever one happens to live. Physicists in different cultural settings might assign different levels of importance to understanding atoms, but atoms remain atoms. However, when it comes to constructs like intelligence, creativity, and wisdom, it is by no means clear that they are precisely the same thing in any culture, and many psychologists believe they are not [5-10]. 
If one wishes to consult experts, an alternative to asking designated experts is to rely on the wisdom of the crowd [11,12], recognizing that crowds are not always wise (but neither are experts). If one wishes to expand upon a traditional post-industrial Western view, one possibility is to look beyond the usual university experts in the West. Some of the best experts might be, as it turns out, hunters, gatherers, farmers, and fishermen living in rural Kenya.

Investigators surveyed rural Kenyans on their conceptions of intelligence [13]. They found that the rural Kenyan conception involves four constructs. Rieko is very close to what conventional Western intelligence tests measure, especially knowledge and analytical cognitive skills. Luoro, in contrast, involves practical skills, including respect for others. Paro involves initiative and trying new things and is similar in many respects to creativity. Winjo involves understanding the various elements and their interrelations in complex situations and is similar to wisdom. These elements form the basis for a broad Western theory of adaptive intelligence [14].

In Kenya, creativity is also perceived more broadly than it is in the West. In particular, it involves imagination but also an ethical element [15]. Such views are widespread across the African continent $[16,17]$. In other words, whereas creativity in the post-industrialized West focuses on novelty and usefulness, creativity in Africa and parts of Asia seems to involve not only doing something novel and useful, but also doing something that is actually good for the world.

Why might we even want to look to this broader conception of creativity today, or at least when this article is being written in mid-2021? Why might a conception of wisdom that integrates creativity with elements of wisdom actually be itself an example of wisdom in the psychological field? As we all know, the world is facing enormous challenges from many different sides (see [14]). Air pollution is a deadly danger and has been associated with more than 4 million deaths per year, as well as with severe and debilitating respiratory illnesses as well as other illnesses [18]. Global climate change is wreaking havoc around the world and is likely only to get worse, causing floods, severe hurricanes, and warming temperatures that will make some parts of the world unlivable that are currently inhabitable [19-21]. Countless deaths and perhaps a million species extinctions can and will continue to be attributed to it. Then there is COVID-19, which has killed over 4 million people as of mid-2021. Many of the deaths could not have been prevented, but cynical politicians around the world are using the pandemic to advance their own political, personal, or economic agendas. At the time this essay is being written, the Governor of Florida in the United States seems to be taking every step possible to make the pandemic worse to gain credibility with "conservative" loyalists and anti-vaccine advocates, despite his state having one of the highest rates of COVID-19 in the country [22]. Florida is now the epicenter of the pandemic in the United States, and the governor appears to be more concerned with political symbolism and his own political advancement than with people dying [23]. The list of problems goes on, but it is not likely to become shorter because so many leaders are often acting in ways that exacerbate rather than solve the problems, such as promoting a view of whether to get vaccinated against COVID-19 as a choice that exercises the individual's "personal freedom." It may be, but it is a personal choice that affects others when an ill person breathes on others, infecting and possibly killing them. Is this choice really so different from drunk driving? Should people be allowed to drive drunk as a matter of "personal freedom," without regard to the consequences of those inadvertently run over by the drunk driver's car?

What would an African perspective on creativity, as described, look like in postindustrialized Western society? Or anywhere, really? I believe a clue can be found in a recently proposed concept of transformational giftedness [24-26]. The basic idea of the concept, building on the concepts of transformational and transactional leadership, is that giftedness can be divided into two main kinds-transactional and transformational [27-29]. Within each of these kinds of giftedness, there are subtypes, as explained below. 
The basic idea is that transactionally gifted individuals are motivated by exchange: They are identified as gifted, and in exchange, they give something back, such as high grades, admission to prestigious universities, employment at prestigious firms, receipt of awards, or whatever, so that whatever criteria were used to identify them thus can be viewed as valid. Transformationally gifted individuals, in contrast, are motivated by the desire to make a positive, meaningful, and potentially enduring difference to the world: They hope, through their creativity, to make the world a better place. Transformationally gifted individuals may also be transactionally gifted-to some extent, they have to be, to get things done-but their main motivation is transformational. The distinction thus can be viewed, to some extent, as a matter of how an individual deploys his or her gifts.

Why is such a distinction even useful? It is useful because, at the present time, what the world appears to lack is not sufficient individuals with high IQ, but rather, sufficient individuals with high enough IQs—-but not necessarily the highest ones-who want to use their gifts and talents to make the world a better place. On the contrary, many appear to be helping the world move in the opposite direction. In many countries of the worldChina, the USSR, Hungary, Poland, Myanmar, and elsewhere-there are partially or fully autocratic governments that firmly control their countries. In other countries, such as the US and Brazil, there are would-be autocrats either in power or waiting in the wings who would like to achieve total control but have not yet gotten there. They use their gifts to maximize achievement of their own goals and care little or not at all about the people for whom they are responsible.

These problems have been the subject of scrutiny for a long time, especially by Nicholas Maxwell [30-33], who has recognized that civilization itself is on a collision course with nature and with itself. Universities, according to Maxwell, seem to have been largely oblivious to the challenges that confront the world, and continue following a dated model of research and education that, however much it may once have seemed plausible, simply no longer is responsive to current world challenges. Maxwell's thinking should lead us to reexamine what universities as well as primary and secondary schools are modeling in their behavior.

\section{What Is Transformational Creativity?}

The rural Kenyan view of creativity-as producing some good for the world-is attractive in view of current realities, but it is unlikely that Westerners are going to change their definition of creativity any time soon. The definition of creativity as involving novelty and usefulness/effectiveness has become too entrenched in Western thinking. Moreover, Western researchers of creativity have found a way to deal with antisocial uses of creativity by labeling such uses exemplars of negative or dark creativity. The opposite, in this work, has sometimes been referred to as positive or light creativity [34-38].

The view of positive creativity seems like an attractive way of focusing people on prosocial uses of creativity [39]. However, the term is more problematical than it first appears to be. For example, one source defines positive creativity as the generation of an idea that is both novel and useful or effective in some way, but that also serves a constructive function [40]. Similar definitions can be found elsewhere [41,42]. The problem, I suggest, is in the last clause: Constructive for whom? Suppose that a would-be autocrat attempts to steal an election, as has happened throughout the world, including in the United States [43]. Was the creativity involved in stealing or attempting to steal an election positively or negatively creative, whether by pressuring the Department of Justice (US) or by allowing only "approved" candidates to run for office (in Hong Kong, Iran, Russia, and many other places)? The attempt may have been negative with respect to the people of the country who get a government they do not want, but it may have been viewed as positive by those who wanted an autocratic government, which, although a minority, may be quite a few people.

Thus, positive, neutral, and negative creativity are always relative to the standard of some group. The Kenyan definition of creativity seems to transcend such relativistic 
attempts and to focus instead on a common good. This view of creativity used for a common good brings us into the territory of wisdom-the use of skills and knowledge for a common good [44,45]. Just as transformational giftedness involves directing one's gifts, in general, toward a common good, so can we define transformational creativity as directing one's creativity, in particular, toward a common good. Thus, stealing an election may serve the purposes of some people, but it does not serve the common good. Most people do not want an election stolen and they are not benefited by its being stolen. On the contrary, they experience a loss when the election is stolen from them.

Transformational creativity differs from positive creativity, at least as defined above, in that it is not merely positive for one individual or one group or another, but good for people (and the world, including nonhuman animals and, arguably, plants) in general. It is creativity used to make the world a better place. It differs from ordinary creativity. Someone working for a tech company who devises novel and useful algorithms for convincing people to click more or spend more time on various websites may be creative, and even positively creative with respect to the tech company's bottom line, but they are not transformationally creative according to this definition.

A challenging question is that of who determines the common good. Obviously, there is no individual who resides outside a sociocultural context who can make such a judgment in a way that is free of a sociocultural perspective and, possibly, of bias. Rather, people need to ask challenging questions that sometimes have answers that are difficult to obtain: (a) Who benefits from a course of action, and how great are the benefits? (b) Who loses from a course of action, and how great are the losses? (c) Who is unaffected by a course of action? (d) What is an optimally fair and just assessment of the relative costs and benefits?

There are no objective answers to such questions, but the greater problem, I would argue, is not that people cannot achieve fairness and justice; it is that they do not even try. When one surveys major conflicts around the world in the present and past, such as that between Israelis and Palestinians, or between colonists and Native Americans in American history, to what extent has each side made any serious effort to take the needs of the other side into account? The greatest difficulty in attaining a common good is simply the lack of effort. In the United States, for example, the historical treatment of Native Americans scarcely can be chalked up to anyone's real conception of a common good.

People often are tribal in their instincts, and often their tribalism prevents them even from considering in any fair way the interests of other people. China wants to extend its hegemony to Taiwan: Its question is how to do it. It may see Taiwan as part of China, but increasingly, it sees other countries' lands as part of China [46]. Empires have always tried to expand, going back to ancient Rome and farther. There is nothing new under the sun when it comes to colonization, a lesson my own country, the United States, apparently has yet to learn. It has a history of colonialism extending all the way from the distant past to the present (e.g., in Puerto Rico).

\section{Kinds of Creativity}

Using the framework of transactional and transformational creativity, one can view various kinds of creativity, following the kinds of giftedness (see [25]). These are summarized in Table 1. Consider each kind and how it plays out on the world stage.

\section{Unidentified Creativity-Type 1}

Much of the creativity in the world is unidentified, which may mean that it is waiting to be identified. For example, the creativity of Van Gogh in his paintings was amazing, but for the most part, discovered only after Van Gogh died. Gregor Mendel's creativity in working out the mechanisms of inheritance was largely unknown before his death. Of course, we have no way of knowing how much creativity, including potentially Big-C (worldchanging) creativity [47], is out there. The world is without doubt full of extraordinary ideas few of us know about. 
There also may be people, not just products, with unidentified creativity. These people, living in conditions that never give them a chance to exhibit their creativity, are lost precious human resources. They may grow up in societies that suppress creativity, may have been imprisoned because of their creativity, or may have done creative things that, quite simply, they did not know how to promote, or did not even try to promote.

Table 1. Deployment of giftedness: Four categories of utilization of gifts *.

\begin{tabular}{|c|c|c|}
\hline Kind of Creativity & Category Identification & Definition \\
\hline Unidentified & Type 1 & $\begin{array}{c}\text { The individual is never identified as creative despite their } \\
\text { creative potential }\end{array}$ \\
\hline Transactional Creativity & & $\begin{array}{l}\text { The individual is expected to perform in a creative way in } \\
\text { exchange for being identified or employed }\end{array}$ \\
\hline Inert Creativity & Type 2 & $\begin{array}{l}\text { The individual fails to act creatively even though they } \\
\text { were identified as creative or hired because they were } \\
\text { deemed to be creative }\end{array}$ \\
\hline Fully Transactional Creativity & Type 3 & $\begin{array}{l}\text { The individual gives back creatively in exchange for } \\
\text { having been identified as, or employed to be creative }\end{array}$ \\
\hline Transformational Creativity & & $\begin{array}{l}\text { The individual seeks to make positive, meaningful } \\
\text { creative change for a common good }\end{array}$ \\
\hline Self-Transformational Creativity & Type 4 & $\begin{array}{l}\text { The individual transforms themselves creatively but does } \\
\text { not seek to transform others }\end{array}$ \\
\hline Other-Transformational Creativity & Type 5 & $\begin{array}{l}\text { The individual creatively transforms others but } \\
\text { not themselves }\end{array}$ \\
\hline $\begin{array}{l}\text { Fully Transformational (Self }+ \text { Other } \\
\text { Utilized) Creativity }\end{array}$ & Type 6 & $\begin{array}{l}\text { The individual creatively transforms both themselves } \\
\text { and others }\end{array}$ \\
\hline Pseudo-Transformational Creativity & & $\begin{array}{l}\text { The individual pretends to produce creative } \\
\text { transformation while seeking only to use their creativity } \\
\text { to advance themselves }\end{array}$ \\
\hline $\begin{array}{c}\text { Self-Destructive Pseudo-Transformational } \\
\text { Creativity }\end{array}$ & Type 7 & $\begin{array}{l}\text { The individual, in seeking creatively to advance } \\
\text { themselves, destroys themselves in the process }\end{array}$ \\
\hline $\begin{array}{c}\text { Other-Destructive Pseudo-Transformational } \\
\text { Creativity }\end{array}$ & Type 8 & $\begin{array}{l}\text { The individual, in seeking creatively to advance } \\
\text { themselves, destroys others in the process }\end{array}$ \\
\hline $\begin{array}{c}\text { Fully Destructive Pseudo-Transformational } \\
\text { Creativity }\end{array}$ & Type 9 & $\begin{array}{l}\text { The individual, in seeking creatively to advance } \\
\text { themselves, destroys themselves and others }\end{array}$ \\
\hline
\end{tabular}

* This table is adapted and modified from Table 1 in [25]: Sternberg, R.J. (2021). Identification for utilization, not merely possession, of gifts: What matters is not gifts but rather deployment of gifts. Gifted Education International, DOI: 10.1177/02614294211013345.

\section{Transactional Creativity}

Transactional creativity, as mentioned earlier, is creativity that is exhibited primarily as an exchange. The individual is motivated by a reward [48-51]. The reward might be extrinsic - money, awards, fame; or it might be intrinsic - the feeling of a job well done. In the latter case, the transaction is essentially with oneself. Creativity is often driven by intrinsic motivation; but intrinsic motivation, on this view, can be transactional. One is not necessarily trying to make the world a better place. On the contrary, some people seem to take pleasure and feel a sense of intrinsic accomplishment in making the world worse, such as, at the extreme, a torturer in the Spanish Inquisition (or, unfortunately, today) who takes pleasure in using creativity to devise novel and, to the torturer, useful ways to harm others.

\subsection{Inert Creativity-Type 2}

Inert creativity is a promise unkept. Perhaps someone performs well on a test of creativity, such as the Torrance Tests of Creative Thinking (TTCT) [52,53], but then proves not to be creative in their work. Or someone is hired for their creativity but cannot bring it 
to bear upon the particular tasks for which they were hired. Their creativity is inert-it is not activated. For example, if someone is hired to create advertisements for a new product, and the advertisements fail to excite interest or to increase revenue, the creator's creativity was inert, at least in this instance.

Such instances are probably common, and not just with creativity. So many people do well on standardized tests of intellectual skills, only to flub when it comes to dealing with life. The problem is that tests are only modest predictors. There is a substantial difference, for example, between finding unusual uses of a paper clip [54] and being creative in life. Conventional assessments of creativity simply cannot replicate the emotional stakes and the magnitude and scope of real-world problems that challenge people's creativity [55].

\subsection{Fully Transactional Creativity-Type 3}

Fully transactional creativity is successful creativity, in the sense that one is identified as creative and then gives back the creativity that is expected, by others, by oneself, or by both. It goes beyond standard measurements of creativity. When people are hired for creative jobs, the deal is transactional. The people may enjoy being creative-but it is still transactional. What matters in terms of the present taxonomy is not the motivation for the creativity, but rather, the deployment of the creativity.

For example, the creative employees in most tech firms use their creativity in ways that they find challenging and meaningful and that improve the bottom lines of their organizations. However, whether the work they do improves society is often an open question and is typically not a main motivation for what they do. Much of the work may be positively creative in some ways (some people profit from it-for example, in acquiring surveillance devices) and negatively creative in other ways (other people lose from it by being placed under surveillance, often without their knowledge).

\section{Transformational Creativity}

Transformational creativity is creativity deployed to make the world a better place-to make a positive, meaningful, and potentially enduring difference to the world. People who are transformationally creative often also are transactionally creative-they have paying jobs, like most other people, and they care about their work. What differentiates them as transformationally creative is that they go beyond transaction-they use their creativity to affect positive change that seeks a common good. They are creative in the Kenyan sense.

\subsection{Self-Transformational Creativity-Type 4}

Self-transformational creativity is deployed when one uses one's creativity to improve and enrich one's own life, but when the creativity does not necessarily affect others. For example, someone might creatively compose music or perform music but have only themselves as an audience. Their work might seem to be little-c (see [47]), but it also might be potentially Pro-c in the sense that it is equally creative to that of talented professionals in the field. The individual just chooses to keep the work to themselves.

Retired people, for example, often take up a hobby that they have had, such as playing music or writing fiction, and then turn new attention to these hobbies, working their hardest to produce creative products. However, at that point in their lives, they might not feel a need for a large audience, or even for any audience beyond themselves. Their work may greatly enrich their own lives and make a positive and meaningful addition to their lives without affecting the lives of others.

\subsection{Other-Transformational Creativity-Type 5}

Other-transformational creativity is transformational for others but not for oneself. The writings of Sylvia Plath, Virginia Woolf, David Foster Wallace, Ernest Hemingway, and Anne Sexton transformed the lives of many, but it did not save the authors from misery or, ultimately, from committing suicide. Creative people sometimes have mental-health challenges that make their own lives miserable [56]. Other-transformational creativity is 
not necessarily associated with poor mental health. The creativity of Mahatma Gandhi and Nelson Mandela in statesmanship made the lives of millions of others much better, but their own lives were highly challenging.

\subsection{Fully Transformational Creativity-Type 6}

Fully transformationally creative individuals benefit both others and themselves through their creativity. They manage to contribute to others without sacrificing or inadvertently destroying their own lives. It is always difficult to pinpoint whose life is happy and whose is not because one never knows what is going on beneath the surface. Moreover, everyone's life has challenges. However, helping others does not have to mean sacrificing one's own life. Fully transformationally creative people find fulfillment both for themselves and for others.

\section{Pseudo-Transformational Creativity}

Pseudo-transformational creativity is presented as improving the world when in fact it is destructive to the common good. Pseudo-transformationally creative individuals find ways to make the world worse under the guise of making it better.

\subsection{Self-Destructive Pseudo-Transformational Creativity-Type 7}

These individuals pretend to be creative for a good cause but end up destroying themselves through their pretense of doing good. Makers of ingenious explosive devices that are used by suicide bombers occasionally blow themselves up in the process of creating their destructive devices. They may not even have succeeded in harming any person besides themselves. They often claim to be intent on saving the world for some religion or ideology but in fact are only causing harm, ultimately, in these cases, to themselves. During the insurrection at the Capitol building in January 2021, a number of individuals bragged on social media about the creative ways they had found to breach the Capitol building. Those who have been discovered have repaid themselves with infamy, fines, imprisonment, and in at least one case, death.

\subsection{Other-Destructive Pseudo-Transformational Creativity-Type 8}

Other-destructive pseudo-transformationally creative individuals cause harm to others. For example, I would suggest that at least some of the individuals in social-media enterprises have become other-destructively pseudo-transformationally creative. While claiming to provide a valuable service to humanity, they instead have devised ways of addicting people to their social media and to the often harmful and false propaganda-the "fake news"- that emanates from it.

In tech, as in leadership, people often are slow to recognize other-destructive pseudotransformational creativity. Former US president Donald Trump tried multiple novel and, to him, potentially useful ways of trying to stay in power [57]. Fortunately, they all failed.

To this day, as is often the case, many people do not recognize other-destructive pseudo-transformational creativity when it stares them in the face. That is, indeed, what pseudo-transformational creativity is about-disguising one's ill intentions behind a cloak of righteousness. It is scarcely a new game. There always have been people who fall for it, and presumably, there always will be.

\subsection{Fully Destructive Pseudo-Transformational Creativity-Type 9}

Fully destructive pseudo-transformational creativity hurts everyone. It is a form of dark creativity see [34-38]. It is the creativity of, say, Andrew Fastow, who helped to bring down Enron through a series of ingenious but illegal financial machinations, or of Bernie Madoff, who cleverly but perniciously brought financial chicanery through a pyramid scheme to new depths. The individuals find ingenious ways of pretending to do right, while harming others and ultimately themselves. Both Hitler and Mussolini met violent 
deaths. Charismatic leaders always deserve a second look: Is their charisma a way of producing positive social change, or of hiding negative changes?

\section{Conclusions}

What, exactly, is transformational creativity? It is, I believe, what links together creativity and wisdom. It is creativity applied positively to the common good in a way that recognizes that the reason we don't solve problems often is because we are solving the wrong problem! Transformational creativity is not just about transformational solutions, but also about transformations of misdefined problems to recognize what the problems are we really need to solve. For example, the problem of poverty can be addressed in the short term by financial help; but in the long term, it only can be solved by providing the education, resources, and in some cases, professional socialization that will enable people to become meaningfully employed. That is, a long-term solution requires a different definition of the problem from a short-term fix. Transformational creativity has the positive ethical purpose that is found in wisdom, but that often is missing from ordinary creativity. It is creativity that fits the ethical and other constraints that inhere in a wide variety of everyday family, local, national, and international situations [58]. Always, however, the opportunity to be transformationally creative, and the ways in which one can be transformationally creative, depend on the cultural and temporal contexts in which one lives.

Obviously, not everyone who is creative in a society will be transformationally creative. There is plenty of room for those who are simply transactionally creative. However, it can be a serious problem if transformational creativity is sparse or absent. For much of the history of the United States, for example, creativity seemed little to be rewarded or even studied. In recent years, as society has come to realize how important creativity is to the flourishing of society, the appreciation of creativity has risen. Today, creativity is valued and studied widely (see [3,41]). Its importance is largely recognized. However, the definition of creativity in the West, unlike in the Kenyan sample (see [15]), does not include a positive moral or ethical purpose. At the same time, we need to recognize that in Kenya, the West, or anyplace else, there is no single definition of creativity that fits all folk (implicit) theories or explicit theories. People, wherever they live, regardless of time or place, often adapt constructs to meet the challenges in their lives. What promoters of creativity did not realize when promoting creativity training and development is that creativity so often can be used for ill purposes-to create devices that increase air pollution, global warming, illegal surveillance, and more. I suggest the time has come to recognize that what we need to develop in young people is not merely creativity, but rather, transformational creativity. We have the opportunity. We need to avail ourselves of it.

Funding: This project received no external funding.

Institutional Review Board Statement: This project involved no original data collection.

Informed Consent Statement: This project had not participants and hence no informed consent statement.

Data Availability Statement: This project involved no collection of original data.

Conflicts of Interest: There are no conflict of interest in this project.

\section{References}

1. Sternberg, R.J. Implicit theories of intelligence, creativity, and wisdom. J. Personal. Soc. Psychol. 1985, 49, 607-627. [CrossRef]

2. Sternberg, R.J. (Ed.) Cambridge Handbook of Intelligence, 2nd ed.; Cambridge University Press: New York, NY, USA, 2020.

3. Glaveanu, V.P.; Kaufman, J.C. Creativity: An historical perspective. In Cambridge Handbook of Creativity, 2nd ed.; Kaufman, J.C., Sternberg, R.J., Eds.; Cambridge University Press: New York, NY, USA, 2019; pp. 9-26.

4. Sternberg, R.J.; Glück, J. (Eds.) Cambridge Handbook of Wisdom; Cambridge University Press: New York, NY, USA, 2019.

5. Sternberg, R.J. (Ed.) Cultural approaches to intelligence. In Human Intelligence: An Introduction; Cambridge University Press: New York, NY, USA, 2020; pp. 174-201.

6. Berry, J.W. Radical cultural relativism and the concept of intelligence. In Culture and Cognition: Readings in Cross-Cultural Psychology; Berry, J.W., Dasen, P.R., Eds.; Methuen: York, UK, 1974; pp. 225-229. 
7. Berry, J.W. Intelligence as ecological and cultural adaptation. In Intelligence in Context; Sternberg, R.J., Preiss, D.D., Eds.; Palgrave-Macmillan: Cham, Switzerland, in press.

8. Greenfield, P.M. The cultural evolution of IQ. In The Rising Curve: Long-Term Gains in IQ and Related Measures; Neisser, U., Ed.; American Psychological Association: Washington, DC, USA, 1998; pp. 81-123.

9. Laboratory of Comparative Human Cognition. Culture and intelligence. In Handbook of Human Intelligence; Sternberg, R.J., Ed.; Cambridge University Press: New York, NY, USA, 1982; pp. 642-719.

10. Cole, M.; Cigagas, X.E. Culture and cognition. In Handbook of Cultural Developmental Science; Bornstein, M.H., Ed.; Psychology Press: New York, NY, USA, 2010; pp. 127-142.

11. Abercrombie, J. The Wisdom of Crowds; Orbit: London, UK, 2021.

12. Surowiecki, J. The Wisdom of Crowds; Anchor: New York, NY, USA, 2005.

13. Grigorenko, E.L.; Geissler, P.W.; Prince, R.; Okatcha, F.; Nokes, C.; Kenny, D.A.; Bundy, D.A.; Sternberg, R.J. The organization of Luo conceptions of intelligence: A study of implicit theories in a Kenyan village. Int. J. Behav. Dev. 2001, 25, 367-378. [CrossRef]

14. Sternberg, R.J. Adaptive Intelligence: Surviving and Thriving in a World of Uncertainty; Cambridge University Press: New York, NY, USA, 2021.

15. Gacheru, M.; Opiyo, M.; Smutny, J.F. Children's creative thinking in Kenya. Child. Educ. 1999, 75, 346-349. [CrossRef]

16. Niu, W. Eastern-Western views of creativity. In Cambridge Handbook of Creativity; Kaufman, J.C., Sternberg, R.J., Eds.; Cambridge University Press: New York, NY, USA, 2019; pp. 448-461.

17. Mpofu, E.; Myambo, K.; Mogaji, A.A.; Mashego, T.-A.; Khaleefa, O.H. African perspectives on creativity. In International Handbook of Creativity; Kaufman, J.C., Sternberg, R.J., Eds.; Cambridge University Press: New York, NY, USA, 2006; pp. $448-461$.

18. World Health Organization. Air Pollution. 2019. Available online: https://www.who.int/airpollution/en/ (accessed on 6 September 2021).

19. Fears, D. One Million Species Face Extinction, UN Report Says. And Humans Will Suffer as a Result. Washington Post. 6 May 2019. Available online: https:/ / www.washingtonpost.com/climate-environment/2019/05/06/one-million-species-face-extinctionun-panel-says-humans-will-suffer-result/?utm_term=.5a826356bc1e (accessed on 6 September 2021).

20. Rettner, R. More Than 250,000 People May Die Each Year Due to Climate Change. Live Science. 17 January 2019. Available online: https:/ / www.livescience.com/64535-climate-change-health-deaths.html (accessed on 6 September 2021).

21. Kahan, D.M.; Peters, E.; Wittlin, M.; Slovic, P.; Ouelette, L.L.; Braman, D.; Mandel, G. The polarizing impact of science literacy and numeracy on perceived climate change risks. Nat. Clim. Chang. 2012, 2, 732-735. Available online: https: //www.nature.com/articles/nclimate1547 (accessed on 6 September 2021). [CrossRef]

22. Krugman, P. "Freedom," Florida and the Delta Variant Disaster. New York Times. 2 August 2021. Available online: https: / /www.nytimes.com/2021/08/02/opinion/Covid-Florida-vaccines.html?searchResultPosition=2 (accessed on 6 September 2021).

23. Greenwood, M.; Manchester, J. Florida Becomes Epicenter of COVID-19 Surge. The Hill. 3 August 2021. Available online: https: / / thehill.com/homenews / campaign/566168-florida-becomes-epicenter-of-covid-19-surge?userid=845061 (accessed on 6 September 2021).

24. Sternberg, R.J. Transformational Giftedness: Rethinking Our Paradigm for Gifted Education. Roeper Rev. 2020, 42, 230-240. [CrossRef]

25. Sternberg, R.J. Identification for utilization, not merely possession, of gifts: What matters is not gifts but rather deployment of gifts. Gift. Educ. Int. 2021. [CrossRef]

26. Sternberg, R.J.; Chowkase, A.; Desmet, O.; Karami, S.; Landy, J.; Lu, J. Beyond transformational giftedness. Educ. Sci. 2021, 11, 192. [CrossRef]

27. Bass, B.M. Transformational Leadership: Industrial, Military, and Educational Impact; Lawrence Erlbaum Associates: Mahwah, NJ, USA, 1998.

28. Bass, B.M.; Avolio, B.J.; Atwater, L. The Transformational and Transactional Leadership of Men and Women. Appl. Psychol. 1996, 45, 5-34. [CrossRef]

29. Bass, B.M.; Riggio, R.E. Transformational Leadership: A Comprehensive Review of Theory and Research, 2nd ed.; Psychology Press: London, UK, 2006.

30. Maxwell, N. The World Crisis-And What to Do about It: A Revolution for Thought and Action; World Scientific: Singapore, 2021.

31. Maxwell, N. The key to the solution of the world crisis we face. Hum. Aff. 2020, 31, 21-39. [CrossRef]

32. Maxwell, N. How wisdom can help solve global problems. In Applying Wisdom to Contemporary World Problems; Sternberg, R.J., Nusbaum, H., Glueck, J., Eds.; Palgrave Macmillan: London, UK, 2019; pp. 337-380.

33. Maxwell, N. Can scientific method help us create a wiser world? In Practical Wisdom in the Age of Technology: Insights, Issues and Questions for a New Millennium; Dalal, N., Intezari, A., Heitz, M., Eds.; Routledge: London, UK, 2016; pp. 147-161.

34. Cropley, D.H. Summary-The dark side of creativity: A differentiated model. In The Dark Side of Creativity; Cropley, D.H., Cropley, A.J., Kaufman, J.C., Runco, M.A., Eds.; Cambridge University Press: New York, NY, USA, 2010; pp. 360-373.

35. James, K.; Taylor, A. Positive creativity and negative creativity (and unintended consequences). In The Dark Side of Creativity; Cropley, D.H., Cropley, A.J., Kaufman, J.C., Runco, M.A., Eds.; Cambridge University Press: New York, NY, USA, 2010; pp. 33-56.

36. Sternberg, R.J. The dark side of creativity and how to combat it. In The Dark Side of Creativity; Cropley, D.H., Cropley, A.J., Kaufman, J.C., Runco, M.A., Eds.; Cambridge University Press: New York, NY, USA, 2010; pp. 316-328. 
37. Jonason, P.K.; Abboud, R.; Tomé, J.; Dummett, M.; Hazer, A. The Dark Triad traits and individual differences in self-reported and other-rated creativity. Personal. Individ. Differ. 2017, 117, 150-154. [CrossRef]

38. Kapoor, H. The creative side of the Dark Triad. Creat. Res. J. 2015, 27, 58-67. [CrossRef]

39. Sternberg, R.J. Positive creativity. In Current Research in Positive Psychology; Kostic, A., Chadee, D., Eds.; Palgrave-Macmillan: Cham, Switzerland, 2021; pp. 33-42.

40. Sternberg, R.J.; Karami, S. Teaching for Positive Creativity. ASCD Express. 8 April 2021, Volume 16. Available online: http: / / www.ascd.org/ascd-express/vol16/num15/teaching-for-positive-creativity.aspx (accessed on 6 September 2021).

41. Kaufman, J.C.; Glaveanu, J.C. An overview of creativity theories. In Creativity: An Introduction; Kaufman, J.C., Sternberg, R.J., Eds.; Cambridge University Press: New York, NY, USA, 2021; pp. 17-30.

42. Clark, K.; James, K. Justice and positive and negative creativity. Creat. Res. J. 1999, 12, 311-320. [CrossRef]

43. Krieg, G. Trump's Attempt to Steal the Election Unravels as Coronavirus Cases Surge. CNN. 22 November 2020. Available online: https:/ / www.cnn.com/2020/11/22/politics/trump-election-results-coronavirus/index.html (accessed on 6 September 2021).

44. Sternberg, R.J. A Balance Theory of Wisdom. Rev. Gen. Psychol. 1998, 2, 347-365. [CrossRef]

45. Sternberg, R.J. The balance theory of wisdom applied to management: Balancing profits with people. In Handbook of Practical Wisdom in Business and Management; Schwartz, B., Bernacchio, C., González-Cantón, C., Robson, A., Eds.; Springer: Cham, Switzerland, 2020. [CrossRef]

46. Kirubakaran, P. China Shares Border with 14 Countries but Has Territorial Disputes with over 18. Republicworld. 15 July 2020. Available online: https: / / www.republicworld.com/world-news/china/china-shares-border-with-14-countries-has-disputeswith-18.html (accessed on 6 September 2021).

47. Kaufman, J.C.; Beghetto, R.A. Beyond big and little: The four c model of creativity. Rev. Gen. Psychol. 2009, 13, 1-12. [CrossRef]

48. Amabile, T.M. The Social Psychology of Creativity; Springer: New York, NY, USA, 1993.

49. Amabile, T.M. Creativity in Context; Westview: Boulder, CO, USA, 1996.

50. Amabile, T.M.; Pillemer, J. Perspectives on the social psychology of creativity. J. Creat. Behav. 2012, 46, 3-15. [CrossRef]

51. Hennessey, B.A. Motivation and creativity. In Cambridge Handbook of Creativity, 2nd ed.; Kaufman, J.C., Sternberg, R.J., Eds.; Cambridge University Press: New York, NY, USA, 2019; pp. 374-395.

52. Torrance, E.P. Torrance Tests of Creative Thinking. Directions Manual and Scoring Guide, Verbal Test Booklet B; Scholastic Testing Service: Bensenville, IL, USA, 1974.

53. Torrance, E.P. The Torrance Tests of Creative Thinking Norms-Technical Manual Figural (Streamlined) Forms A E B; Scholastic Testing Service: Bensenville, IL, USA, 2008.

54. Guilford, J.P. The Nature of Human Intelligence; McGraw-Hill: New York, NY, USA, 1967.

55. Sternberg, R.J. Measuring creativity: A 40+ year retrospective. J. Creat. Behav. 2017, 53, 600-604. [CrossRef]

56. Carson, S.; Yang, E.; Forgeard, M. Creativity and mental health. In Creativity: An Introduction; Kaufman, J.C., Sternberg, R.J., Eds.; Cambridge University Press: New York, NY, USA, 2021; pp. 196-223.

57. Kamarck, E. Did Trump Damage American Democracy? Brookings Institution. Available online: https://www.brookings.edu/ blog/fixgov/2021/07/09/did-trump-damage-american-democracy/ (accessed on 9 July 2021).

58. Corazza, G.E.; Glaveanu, V.P.; Kaufman, J.C. Injecting Creativity in Society for Possible Futures of Improved Ethics and Equity. In Handbook of Social Justice Interventions in Education; Mullen, C.A., Ed.; Springer International Handbooks of Education; Springer: Cham, Switzerland, 2021. [CrossRef] 